\title{
ASSESSING KNOWLEDGE LEVEL OF STAKEHOLDERS ON TRANSPORT INTERCHANGE DESIGN AND OPERATION
}

\author{
Irina YATSKIV (JACKIVA) ${ }^{1^{*}}$, Eftihia NATHANAIL ${ }^{2}$, Mihails SAVRASOVS ${ }^{3}$, \\ Giannis ADAMOS ${ }^{4}$, Lambros MITROPOULOS ${ }^{5}$ \\ ${ }^{1,3}$ Dept of Mathematical Methods and Modelling, Transport and Telecommunication Institute, Riga, Latvia \\ 2, 4, 5 Dept of Civil Engineering, University of Thessaly, Volos, Greece
}

Received 16 January 2018; revised 29 March 2018; accepted 31 May 2018

\begin{abstract}
The paper advances the results of the on-going work conducted within the frame of the European Twinning project ALLIANCE. In the effort to assess educational needs of different stakeholder groups involved in the domain, this paper's main interest is to study knowledge and importance of governance issues and smart solutions, which enable smooth and seamless interconnectivity of alternative transportation modes, and techniques for facilitating decision-making and evaluation of these solutions. Data were collected through a questionnaire web-based survey addressed to different stakeholder groups in Latvia: policy makers, industry, academia/research and students. From the statistical analysis conducted it was concluded that there are differences in the average rating of different thematic areas (i.e. governance, smart solutions, decision-making) by the respondents. Especially stakeholders belonging to policy makers, industry and students valuated their knowledge on Governance and Smart Solutions below average and at the same time these areas as important for carrier development. Recommendations on the adaptation of an education/training program for Latvia were drawn from the above analysis.
\end{abstract}

Keywords: transport interchange, education, training, governance, smart solutions, decision-making, knowledge, stakeholder, questionnaire survey, statistical analysis.

\section{Introduction}

Digital society, combined with strategies that promote sustainability, enhance the promotion of soft modes of transport, public transportation and green logistics. Stakeholders need to identify new strategies to improve quality of life of citizens, so that to set up their planning according to economic competitiveness and business needs, but also to emerging travelling and consuming trends (Nathanail et al. 2016a).

The paper advances the results of the on-going work conducted within the frame of the European Twinning project ALLIANCE. The key concept of the project is to reveal and enable excellence on innovative solutions for intermodal transport interchanges in Latvia, through knowledge transfer and good practice exchanges between the TTI (Latvian research and educational institute) and two leading research and educational institutes with high expertise and know-how in the domain, UTH (Greece) and Fraunhofer IFF (Germany).

According to the Statistical Bureau of Latvia (CSB 2017), transportation and warehousing area is one of key drivers of national economics (12\% in 2015). The main goal of the Latvian Transport Policy Guidelines 2014-2020 (OECD 2017) is to develop the competitive, sustainable co-modal transport system that provides high quality mobility, at the same time effectively using resources. Latvia is an attractive transit country and geographical location remains central to strategically relevant transportation flows connecting major world economies like the United States, European Union, Russia, the Commonwealth of Independent States and the Far East. The transit sector is one of the strongest industrial sectors in Latvia: nearly $90 \%$ of turnover in Latvian ports, more than $80 \%$ of rail cargo, and the major proportion of oil and oil products transported via trunk pipeline systems is transit. More than $8 \%$ of Latvia's employees are engaged in the transportation and servicing of transit cargo. The importance of the transport, transit and storage sector in terms of GDP contribution is substantial at around $9.5 \%$ in 2015 as stated by Investment and Development Agency of Latvia (LIAA 2017).

${ }^{*}$ Corresponding author. E-mail: jackiva.i@tsi.lv 
In order to ensure a sustained response to the continuous growing mobility demand, the Latvian transport sector needs to be developed in a dynamic way and incorporated into the European transport system. The main goal for the sustainable development of Latvia's transport system is to fully integrate Latvia's transport infrastructure with the Trans-European multi-modal transport system. In the National Development Plan 2014-2020 (CCSC 2012) there are noted the following objectives for public transport: improvement of accessibility of public transport services and organizing of a single bus and rail route network to provide possibilities for inhabitants of rural areas to access regional significance centres and national significance centres and the capital.

All these priorities form the core strategies in moving Latvia towards meeting the needs of human resource development, and create a pool of highly competent knowledgeable specialists. According to the article 82 of the National Development Plan 2014-2020 (CCSC 2012), the main required significant aspects in order to improve the competitiveness of Latvian products and services are "a close cooperation with the scientific sector on a commercial basis, encouraging the interest of the private sector to invest in research and innovation" and "an outstanding business environment: predictable, reasonable and supportive to every entrepreneur". Moreover, one of the strategic objectives is to provide advanced research and innovation and higher education, which can be achieved by attracting human resources, developing innovative ideas, improving the research infrastructure, facilitating cooperation between higher education, science and the private sector, as well as by transferring research and innovation to business.

The enhancement of the competitiveness of a region can be expected from third generation universities, as this is where not only education and research are significant but the utilization of knowledge is also crucial as mentioned in Lukovics and Zuti (2013). As a result, the connection between industry and universities deepens, so there is an opportunity of the local utilization of knowledge created in universities, which enhances the competitiveness of the region through the enhancement of the competitiveness of enterprises.

In recent years Latvia has made remarkable progress in its tertiary education attainment rate but issues remain to be addressed to improve the quality of vocational education and training and higher education (EC 2015). And one of the important tasks considers in Latvia: European Inventory on NQF 2016 (CEDEFOP 2017) - strengthening the link between the labour market and education. For instance, adult participation in lifelong learning in Latvia was $5.5 \%$ in 2014 , below the European Union average of $10.7 \%$ (EC 2015).

One of the aims of the ALLIANCE project is to develop educational and training transport program addressing intermodal interconnections. By analysing good practices on interchanges for passenger mobility and freight transportation and an in-depth investigation of the current situation and trends that exist in EU and the Latvia and Baltic Sea region, about the planning and operation of intermodal terminals, project identified existing gaps between the transport industry and practice, and the research, education and training programs in Latvia, which could be fund in Mitropoulos et al. (2017).

In an effort to assess educational needs of different stakeholder groups involved in the domain, this paper's main aim is to study differences in their knowledge attained on present and emerging governance issues and smart solutions, which enable smooth and seamless interconnectivity of transportation modes, and techniques for facilitating decision-making and evaluation of these solutions. Data were collected through a questionnaire survey (web-based) addressed to four stakeholder groups in Latvia: policy makers, industry, academia/research and students. Statistical analysis was done to compare existing knowledge among these groups, to explain where any differences or similarities exist and as a consequence identify specific requirements for educating and training graduate students and professionals. Recommendations on the adaptation of the education/training programs were drawn from the above analysis.

\section{State of the art}

Transport decarbonisation and demographic trends generate new challenges for communities that are called to make an efficient and sustainable management of services and resources. Both economic efficiency as well as sustainability need to be balanced and addressed in a "smart" framework as stated by Hollands (2008). The sustainable transportation infrastructure development is not feasible without the application of advanced technologies in transportation, covering both passenger mobility and freight transportation.

Implementation of advanced technologies into transport over the 21 st century transformed methods and applications that are commonly used to design, operate and maintain transport systems. Transportation Research Circular E-C208 (TRB 2016) defined key transformational technologies in transport as connected and automated vehicles (including shared use services); unmanned aerial systems (drones); internet of things (including smart cities); and cybersecurity and technologies that have the potential to be transformational technologies such as NextGen, 3-D printing and big data. However, a gap exists between the availability of technology and what stakeholders in transport and logistics are using it for. Implementation of new concepts and technologies relies on different factors and one of the most significant is readiness of the end users to accept new solutions, etc.

White Paper (EC 2011) considered three pillars of priorities: (1) people, (2) integration, and (3) technology. The relationship between industry and higher education is changing and deepening and as mentioned by Ernst \& 
Young (EY 2012) industry plays multiple roles: as customer and partner of higher education institutions and, increasingly, as a competitor.

In the context of the European strategy Europe 2020 one of the objectives for Latvian education system is to increase the openness and significance of education systems, by elaborating national qualifications systems and ensuring better compliance of the study achievements with the labour market needs (EC 2010). Developed to meet all needs, tertiary and vocational education should cover the desires of transport related professionals, through a transport program that corresponds to forthcoming challenges, include the hot topics and best practices. It should also cover the need of those who study both at masters and doctoral level in transport and logistics programs or needed short-term training during their carrier. Gartner analysts (Lowendahl et al. 2016) consider that employers are questioning if students are getting the right skills or, at least, if its assignment of traditional credits correlates with students skills and proficiency.

The research by Mateo-Babiano (2017) devotes the education of transport planning professionals in Australia, examines to what extent students are being prepared to enhance their skills that would make them more competitive in the workplace. Transport planning professionals are expected to be well-equipped with the knowledge and skills to address new and emerging urban transport challenges as well as to support the changing mobility and accessibility needs of addressing new and emerging urban transport challenges as well as to support the changing mobility and accessibility needs of communities. Because of this, the higher education sector experiences stronger pressure from industry, government and the public to demonstrate its ability to educate more work-ready graduates, including planning for transport.

In a research by Čižiūnienè et al. (2016) on competencies of human resources in Lithuanian transport sector the respondents indicated, that employers do not offer any training to achieve better activity results but at the same time more than $65 \%$ of the respondents indicated, that they have higher university education. This means that in the times of contemporary and competitive market, the competencies of the specialists in transport sector should upgrade on constant base and especially in sector-specific knowledge and skills.

Given the projected infrastructural developments for Latvia and Baltic countries, port interconnections, rail upgrade and connections with international transport corridors and networks there is a necessity to increase the competence of its educational system in the area of intermodal transport by creating an educational program that adopts its content based to regional needs and European best practices.

In accordance with the results of ALLIANCE project analysis existing research, educational and training programs in transport in Latvia and the Baltic Sea region present an adequate coverage of traditional transport principles and the generic methods that are used in transport for planning and design. However, the first result of deep analysis showed that these courses are not specialized on intermodality (Mitropoulos et al. 2017). It is possible to claim, that the transport education in Baltic countries is national oriented from the point of view of content, language and training material, and therefore integration of the Baltic transport networks with the European transport network should be especially included in transport programmes. Additionally, project ALLIANCE (Nathanail et al. 2016b) identified that standardization of approaches in terms of content and methodology of transport education are absent at national level and joint or intercollegiate programmes (and moreover with international cooperation) among educational institutes in transport area are limited.

\section{Formulation of the educational and training topics}

With the aim of enhancing competence of current and future professionals who work in the domain of transport, in the region of Latvia and other Baltic countries, a competitive educational and training program for University graduate students $(\mathrm{MSc}$ and $\mathrm{PhD}$ ) was designed for Latvia and the region, under the title of Sustainable Transport Interchange Program (STIP). STIP was developed within the frame of the ALLIANCE project (Nathanail et al. 2016b) and has been implemented and approbated during the 1st ALLIANCE Summer School in Riga (Latvia) in July 2017. The program's development followed a thorough analysis of the needs analysis, which revealed the required skills and knowledge for professionals in the domain of transport interchanges by Mitropoulos et al. (2017). The analysis included identification of the requirements for sustainable passenger and freight interchanges, assessment of relevant educational programs and specific topics covered in European Universities, categorization of them into educational areas, and finally composition of twelve course modules comprising the core curriculum of STIP. These modules, grouped in three thematic areas, are the following:

- Governance:

C1. The European policy on intermodal transport;

C2. Building business models for intermodal transport interchanges;

C3. Sustainable development and transportation planning;

C4. Operation and management of intermodal transport systems;

C5. Optimization of intermodal transport systems;

- Smart solutions:

C6. Smart solutions for passenger transport interchanges;

C7. Smart solutions for freight transport interchanges;

C8. Design of passenger transport interchanges;

C9. Design of freight transport interchanges;

C10. Smart equipment for freight transhipment; 


\section{- Decision-making:}

C11. Decision-making methodologies;

C12. Data collection methods.

In parallel, the rapid introduction of new emerging trends (TRB 2016) in the transport domain reveals more topics, which need to be covered in an educational and training program. These topics were also grouped in the three thematic areas. Specifically, under Governance are accumulated all topics, which require certain adaptation of existing governance and operational models, to be applied in transport interchanges. In this area also technological solutions are considered, which have already been developed and implemented in other fields of transport practices. Technological solutions and soft measures, which are being developed specifically for facilitating efficient operation of intermodal interchanges, are grouped under the Smart solutions thematic area. Finally, Decision-making includes topics, which enable a clear assessment of the interchanges' performance. All considered emerging topics are:

- Governance (Utilization of big data for policy-making; Public procurement of innovative sustainable transportation and mobility solutions in urban areas; Innovative organizational and governance concepts for mobility solutions at neighbourhood and district level; Optimization methods improving resilience of interchanges (i.e. under unexpected events); Incorporation of Vehicle-to-Infrastructure (V2I) and Infrastructure-to-Vehicle (I2V) systems and informationsharing in efficient operation and management of interchanges; Shared-use services and solutions promotion interchange sustainability; Unmanned aerial systems in logistics; Benefits of connected-automated vehicles in the operation and management of interchanges);

- Smart solutions (Innovative design methods and green buildings at interchanges; Promoting accessibility, inclusive mobility and equity in interchange design; Information Communication Technologies and cooperative Intelligent Transportation Systems for smart, safe, accurate and reliable interchange operations; Incorporation of alternative fuel vehicles in smart transhipment; 3D printing in supply chain);

- Decision-making (Collection, storage, processing and visualization of big data to support decision-making in transportation).

\section{Methodology}

The methodology implemented for studying the knowledge on the above topics assumed the definition of the target group of a program that accommodates first level learning needs (i.e. university students) but also long-lifeeducational requirements. So, those who are currently being educated, as well as those who practice the profession in the transport industry, were considered. Thus, the target group was discriminated in four stakeholder categories: (1) Academia/Research (AR), (2) Policy Makers (PM), (2) Industry (In), and (4) Students (St). The first consists of persons involved in education and research, the second of those involved in decision-making in the public domain, the third includes mainly professionals of the private sector and the last students, currently obtaining their knowledge on the subject.

An on-line questionnaire survey was conducted and all questions were addressed to the above groups. The questionnaire was composed of two parts. Part A aimed to assess the relevance of the 12 topics, related to the educational requirements of STIP, to the skills required on job.

Part A questioned:

- how important is to have knowledge on the topics;

- how familiar the respondents are with relevant methods/techniques;

- during their university studies, at what level the respondents developed skills;

- how important would it be for their career development to gain skills.

Part $B$ aimed to assess the 15 emerging trends in the domain of intermodal transport mentioned above, and particularly:

- the level that each of them has been introduced in the profession;

- the level of importance in the career development.

The respondents selected from a symmetric Likert scale (1-5): from 1 (not important at all) to 5 (absolutely essential).

The questionnaire also included questions, about which stakeholder category the respondents belong to, age, gender, level of completed studies, identification of on-going studies (if any) and source other than regular university studies that led to knowledge on transportation interchange design and operation.

Analysis included assessment of the following two research questions:

- Research question Q1: Are there any significant differences in the average rating of respondents between different thematic areas (i.e. Governance, Smart solutions, and Decision-making)?

- Research question Q2: Does the stakeholder category affect the rating on the different thematic areas?

The answers for the six questionnaire questions for the 12 STIP and the 15 emerging topics were analysed, based on Wilcoxon test. Average values of the responses were obtained for each of the three thematic areas, thus 18 questions were finally structured and examined.

Also, inter-relationships among the answers on the six questions were examined, through bivariate correlations were conducted and in parallel to associating them with the stakeholder categories.

\section{Analysis and results}

\subsection{The sample}

A total of 45 stakeholders participated in the questionnaire survey, 32 of them are male (71\%) and 13 female $(29 \%)$. The majority of the respondents $(46.7 \%)$ are 
between $26 \ldots 40$ years old, $33.3 \%$ of them between $41 \ldots 65$, $15.5 \%$ between $18 \ldots .25$, and the rest $4.5 \%>65$ years old. A proportion of $37.8 \%$ of stakeholders are coming from industry, $24.4 \%$ of stakeholders are academia and research, students are represented by $22.2 \%$ and $15.6 \%$ of the sample are policy makers. Regarding the educational level of the respondents, it is indicated that the majority of them (48.9\%) holds a master degree diploma, 26.7\% a BSc degree diploma, $15.6 \%$ a $\mathrm{PhD}$ diploma or have advanced graduate work experience, and $8.8 \%$ are high school graduates.

\subsection{Results}

Firstly, correlation analysis between respondents' answers on survey questions was conducted. Table 1 presents the values of correlation and their significance. Results showed that there is positive relationship between two pairs of responses: (1) the importance of knowledge on STIP topics and the importance of these skills for career development, meaning that respondents consider that high knowledge on STIP topics can contribute to their career development (Figure 1); (2) the importance of knowledge on STIP topics and the importance of knowledge on emerging topics for career development, attributing similar importance of knowledge to both current educational topics and emerging trends.

Then, hypothesis testing was conducted for each of the research questions that were formulated. The results are presented in Table 2.

From the results of Table 2, differences arose among the thematic areas. For STIP topics, respondents highlighted that importance of knowledge on governance is significantly higher than on smart solutions and decisionmaking ( $p$-value $<0.05)$. However, they stated that they are more familiar with decision-making than with the other two thematic areas. It was observed that they developed skills during their university studies in relation to
Table 1. Bivariate correlation between questionnaire questions

\begin{tabular}{|c|c|c|c|c|c|}
\hline Questions & Q1 & Q2 & Q3 & Q4 & Q5 \\
\hline $\begin{array}{l}\text { Q1: Impor- } \\
\text { tance of know- } \\
\text { ledge on STIP } \\
\text { topics }\end{array}$ & - & & & & \\
\hline $\begin{array}{l}\text { Q2: Knowledge } \\
\text { on STIP topics }\end{array}$ & 0.2516 & - & & & \\
\hline $\begin{array}{l}\text { Q3: University } \\
\text { skills develop- } \\
\text { ment on STIP } \\
\text { topics }\end{array}$ & 0.1953 & $0.4327^{\star}$ & - & & \\
\hline $\begin{array}{l}\text { Q4: Impor- } \\
\text { tance of } \\
\text { knowledge on } \\
\text { STIP topics } \\
\text { for career } \\
\text { development }\end{array}$ & $0.6284^{*}$ & 0.2469 & 0.0725 & - & \\
\hline $\begin{array}{l}\text { Q5: Exposure } \\
\text { level on emer- } \\
\text { ging topics }\end{array}$ & $0.3837^{*}$ & $0.3039^{\star}$ & $0.4030^{*}$ & 0.1967 & - \\
\hline $\begin{array}{l}\text { Q6: Impor- } \\
\text { tance of } \\
\text { knowledge } \\
\text { on emerging } \\
\text { topics for ca- } \\
\text { reer develop- } \\
\text { ment }\end{array}$ & $0.5199^{*}$ & 0.1429 & 0.1306 & $0.6516^{*}$ & $0.3208^{\star}$ \\
\hline
\end{tabular}

Note: ${ }^{\star}$ marked correlations are significant at $p$-value $<0.05$.

STIP topics mainly on decision-making, as compared to governance $(z=-2.56)$ and smart solutions $(z=-3.57)$. Likewise, they stated that they find more important for their career development to have knowledge on these topics addressing decision-making than smart solutions $(z=-2.49)$ and they attributed a higher rating to decisionmaking than to governance (not significant).

Table 2. Average rating and comparisons among thematic areas

\begin{tabular}{|c|c|c|c|c|c|c|c|c|c|}
\hline \multirow{3}{*}{ Questions } & \multicolumn{6}{|c|}{ Topics } & \multicolumn{3}{|c|}{$z$-statistic } \\
\hline & \multicolumn{2}{|c|}{$\begin{array}{l}\text { Governance } \\
\text { (G) }\end{array}$} & \multicolumn{2}{|c|}{$\begin{array}{l}\text { Smart solutions } \\
\text { (S) }\end{array}$} & \multicolumn{2}{|c|}{$\begin{array}{l}\text { Decision-making } \\
\text { (DM) }\end{array}$} & \multirow{2}{*}{$\begin{array}{l}\text { G vs. } \\
\text { S }\end{array}$} & \multirow{2}{*}{$\begin{array}{l}\text { G vs. } \\
\text { DM }\end{array}$} & \multirow{2}{*}{$\begin{array}{l}\text { S vs. } \\
\text { DM }\end{array}$} \\
\hline & M & $\mathrm{SD}$ & M & $\mathrm{SD}$ & M & SD & & & \\
\hline Q1: Importance of knowledge on STIP topics & 4.08 & 0.55 & 3.89 & 0.56 & 3.96 & 0.89 & $2.03^{*}$ & $2.02^{*}$ & -1.49 \\
\hline Q2: Knowledge on STIP topics & 2.96 & 0.75 & 2.81 & 0.74 & 3.35 & 0.99 & 1.19 & $-2.03^{\star}$ & $-2.88^{\star}$ \\
\hline Q3: University skills development on STIP topics & 2.68 & 0.98 & 2.51 & 0.89 & 3.26 & 1.01 & 0.85 & $-2.56^{*}$ & $-3.57^{\star}$ \\
\hline $\begin{array}{l}\text { Q4: Importance of knowledge on STIP topics for } \\
\text { career development }\end{array}$ & 3.87 & 0.76 & 3.67 & 0.79 & 4.10 & 0.96 & 1.25 & -1.76 & $-2.49^{\star}$ \\
\hline Q5: Exposure level on emerging topics & 2.66 & 0.90 & 2.47 & 0.95 & 3.02 & 1.21 & 0.912 & -1.40 & $-2.05^{\star}$ \\
\hline $\begin{array}{l}\text { Q6: Importance of knowledge on emerging topics } \\
\text { for career development }\end{array}$ & 3.39 & 0.73 & 3.32 & 0.79 & 4 & 0.92 & 0.28 & $-3.42^{*}$ & $-3.46^{*}$ \\
\hline
\end{tabular}

Notes: $\mathrm{M}$ - average rating; SD - standard deviation; ${ }^{\star}$ statistically significant ( $p$-value $\left.<0.05\right)$. 


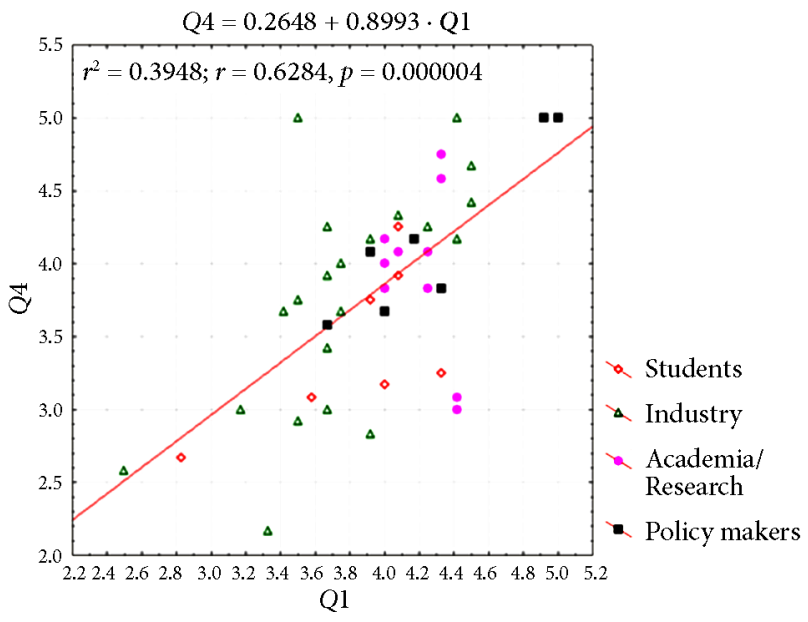

Figure 1. The importance of knowledge on STIP topics and its importance for the respondents' career development

For emerging topics, respondents also expressed that they are more exposed to decision-making than to smart solutions $(z=-2.05)$ and governance (not significant) and therefore attributed higher importance to decision-making as compared to the other two thematic areas.

Of the most significant research questions, are those which refer to the differences in responses on all topics among stakeholders categories. The average rating of answers was calculated for the categories: AR - Academia/ Research, PM - Policy Makers, In - Industry, St - Students and per thematic area. The results of this analysis are presented in Table 3.

The analysis of the results for the first question shows that for all thematic areas received high ratings. In particular to knowledge, Academia/research and Policy makers indicated higher importance as compared to Students and Industry. This could be explained, by the fact, that probably the Students do not have any vision of how to apply received knowledge, meanwhile the Industry representatives have a lack of knowledge in these areas. On the other hand Students and Industry representatives gave highest rating to the importance of knowledge on Governance, as relevant topics are more familiar to them.

Based on the response on the second question, it is seen that all stakeholders believe that they are more familiar with topics on Decision-making as compared to topics of the other two thematic areas, with an average value of 3.33. The rest thematic areas were rated lower, thus it can be concluded that stakeholders have lack of knowledge in Governance and Smart solutions.

Most interesting findings are related to the responses on the third question. Specifically, policy makers pointed out that they gained low skills in Governance and Smart solutions, as compared to the rest, who indicated higher rating to skills and knowledge in all areas. However, it should be indicated, that rating on skills is below 3.5 for all stakeholder categories and thematic areas, with Decision-making receiving the highest rating by all stakeholders. The low rating of the skills in Governance and Smart solutions by the Policy makers, could be related with their older ages, so it means that their studies in the university did not focus on the field of transport intermodality and interchanges. To demonstrate better the differences in rating level of skills gained per stakeholder category and thematic area, a web diagram was constructed and is presented in Figure 2.

The answers on question Q4 regarding importance of knowledge of STIP topics in career development indicated that students consider it of lower importance as compared to the other stakeholder categories. This is understandable, as students are the least exposed to real applications in a business domain, where skills play a role in career development as compared to the other categories. On the contrary, the other three stakeholder categories believe that knowledge is important, and especially in Decisionmaking (Figure 3).

The interesting findings from the analysis of the response on question Q5 is that only Policy makers indicated

Table 3. Average rating and comparisons among stakeholder categories

\begin{tabular}{|c|c|c|c|c|c|c|c|c|c|c|c|c|}
\hline \multirow{2}{*}{ Questions } & \multicolumn{4}{|c|}{ Governance (G) } & \multicolumn{4}{|c|}{ Smart solutions (S) } & \multicolumn{4}{|c|}{ Decision-making (DM) } \\
\hline & $\mathrm{AR}$ & PM & In & St & $\mathrm{AR}$ & PM & In & St & $\mathrm{AR}$ & $\mathrm{PM}$ & In & St \\
\hline $\begin{array}{l}\text { Q1: Importance of knowledge } \\
\text { on STIP topics }\end{array}$ & 4.26 & 4.37 & 3.92 & 3.97 & 4.10 & 4.11 & 3.66 & 3.71 & 4.35 & 4.50 & 3.64 & 3.79 \\
\hline $\begin{array}{l}\text { Q2: Knowledge on STIP } \\
\text { topics }\end{array}$ & 3.30 & 2.74 & 2.93 & 2.74 & 3.06 & 2.69 & 2.78 & 2.69 & 3.55 & 3.29 & 3.36 & 3.14 \\
\hline $\begin{array}{l}\text { Q3: University skills } \\
\text { development on STIP topics }\end{array}$ & 3.04 & 2.09 & 2.65 & 2.86 & 2.74 & 2.14 & 2.45 & 2.71 & 3.50 & 3.29 & 3.14 & 3.29 \\
\hline $\begin{array}{l}\text { Q4: Importance of knowledge } \\
\text { on STIP topics for career } \\
\text { development }\end{array}$ & 3.96 & 4.17 & 3.81 & 3.60 & 3.82 & 4.06 & 3.60 & 3.26 & 4.2 & 4.57 & 4.10 & 3.50 \\
\hline $\begin{array}{l}\text { Q5: Exposure level on } \\
\text { emerging topics }\end{array}$ & 2.91 & 3.14 & 2.47 & 2.36 & 2.58 & 3.19 & 2.24 & 2.29 & 2.8 & 3.71 & 3.14 & 2.29 \\
\hline $\begin{array}{l}\text { Q6: Importance of knowledge } \\
\text { on emerging topics for career } \\
\text { development }\end{array}$ & 3.61 & 3.86 & 3.13 & 3.36 & 3.37 & 3.59 & 3.25 & 3.21 & 3.9 & 4.42 & 3.86 & 4.00 \\
\hline
\end{tabular}




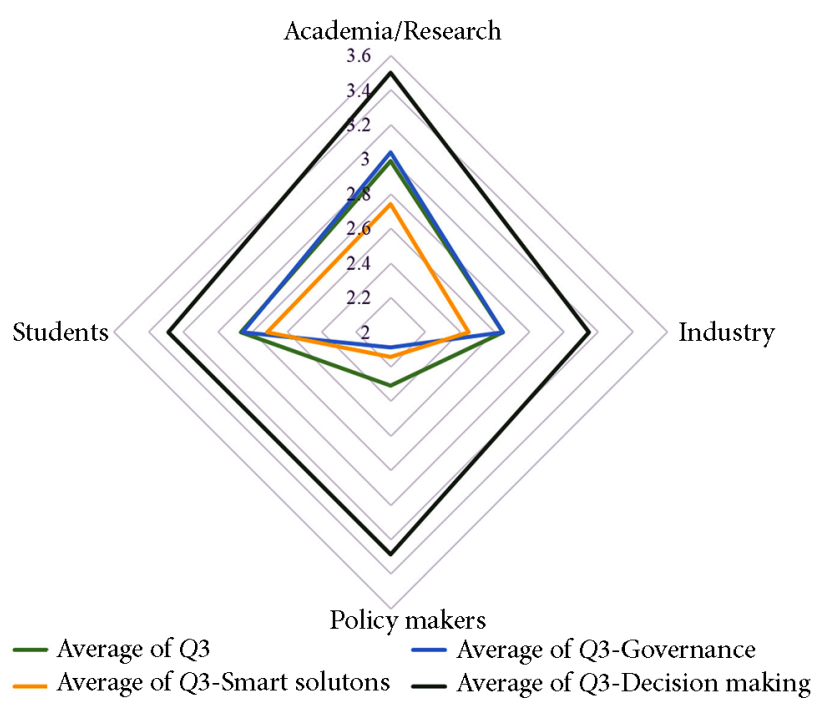

Figure 2. Rating of the level of developed skills

higher exposure level in decision-making in emerging topics as compared to other thematic areas and stakeholder categories. Exposure in Smart solutions received the highest rating in all categories, as this coincides with the low level of Smart solutions introduced in Latvia. At the same time the answers on question Q6 indicated that the Decision-making is considered of highest importance for all stakeholder categories, followed by Governance and then by Smart solutions, except of the Industry, who indicated more interest to Smart solutions and lower level for Governance. The students indicated almost the same level for Governance and Smart solutions. The highest ratings here were provided by Policy makers in all thematic areas, indicating awareness of this sector on emerging needs in the domain.

\section{Conclusions}

The sustainable transportation infrastructure development is not feasible without the application of modern knowledge and skills in advanced technologies in transportation, covering both passenger and freight transport.

The research analysed the dependence of the existing knowledge, importance and requirements for skills and competence on job on different stakeholder categories: Policy Makers, Industry, Academia/Research and Students; and the differences in the average rating of stakeholders between different topics (i.e. Governance, Smart solutions, Decision-making). The gaps identified in research were used for focusing on current and future needs in knowledge of Latvian stakeholders and developing the new variant of STIP for long-life education to provide support to business and public authorities.

Development of (vocational) training programs to transform research results and findings into (good) practice should be delivered to students, post-doctoral fellows, professional practitioners and general staff from the domains of science, market and industry as well as to general

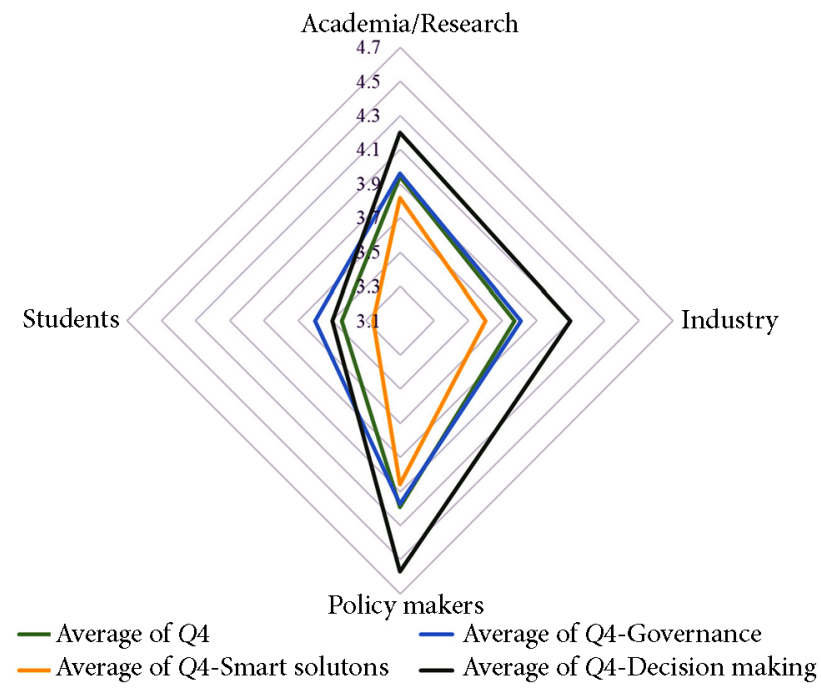

Figure 3. Rating of the importance of knowledge in career development

public, to help them promote impact and prominence of research.

The offered for Academia STIP will deliver services addressed to research, development and innovation for enhancing transport for professionals who work or/and collaborate with stakeholders in the region of Latvia. It will also cover the needs of those who study both at undergraduate and post graduate level transport and ICTrelated courses by providing opportunities for exchanges and short-term training with partner countries.

Knowledge, experience and best practice transfer from academia to industry through academic and longlife education and training will raise the R\&I\&D capacity of Latvia in the domain of the advanced technologies application in transportation field in order to make Latvia competitive in the global market and enable strength of economy development.

\section{Acknowledgements}

This paper is based on the work that has been conducted in the framework of the ALLIANCE project ( $h t t p: / / a l l i-$ ance-project.eu), which has received funding from the $\mathrm{EU}$ Horizon 2020 Research and Innovation Programme. The authors would like to thank both the consortium of the project and the European Commission.

\section{References}

CCSC. 2012. National Development Plan of Latvia for 20142020. Cross-Sectoral Coordination Centre (CCSC) of the Republic of Latvia. 71 p. Available from Internet: https:// rio.jrc.ec.europa.eu/en/library/national-development-planlatvia-2014-2020

CEDEFOP. 2017. Latvia: European Inventory on NQF 2016. European Centre for the Development of Vocational Training (CEDEFOP). 12 p. Available from Internet: http://www. cedefop.europa.eu/files/latvia_-_european_inventory_on_ nqf_2016.pdf 
CSB. 2017. Statistics on the Production of Manufactured Goods. Central Statistical Bureau of Latvia (CSB). Available from Internet: https://www.csb.gov.lv/en

Čižiūnienè, K.; Vaičiūtè, K.; Batarlienè, N. 2016. Research on competencies of human resources in transport sector: Lithuanian case study, Procedia Engineering 134: 336-343. https://doi.org/10.1016/j.proeng.2016.01.016

EC. 2015. The European Higher Education Area in 2015: Bologna Process Implementation Report. European Commission/ EACEA/Eurydice, Luxembourg: Publications Office of the European Union. 304 p. https://doi.org/10.2797/99035

EC. 2011. White Paper: Roadmap to a Single European Transport Area - Towards a Competitive and Resource Efficient Transport System. $\operatorname{COM(2011)~} 144$ final. 28.3.2011, Brussels. Available from Internet: http://eur-lex.europa.eu/legal-content/EN/ ALL/?uri=CELEX:52011DC0144

EC. 2010. Europe 2020: a Strategy for Smart, Sustainable and Inclusive Growth. Communication from the Commission. $\operatorname{COM}(2010) 2020$ final. 3.3.2010, Brussels. 35 p. Available from Internet: https://eur-lex.europa.eu/legal-content/EN/ ALL/?uri=celex:52010DC2020

EY. 2012. University of the Future: a Thousand Year Old Industry on the Cusp of Profound Change. 31 p. Ernst \& Young (EY), Australia.

Nathanail, E.; Adamos, G.; Mitropoulos, L.; Yatskiv (Jackiva) I.; Kabashkin, I.; Savrasovs, M.; Malnaca, K.; Matzner, K. 2016 a. Good Practices of Research, Educational and Training Programs on Smart Solutions for the Interconnection of Transportation Networks. ALLIANCE Deliverable D2.1. Project No 692426 Enhancing Excellence and Innovation Capacity in Sustainable Transport Interchanges. 164 p. Available from Internet: http://alliance-project.eu/wp-content/uploads/2016/03/ALLIANCE_D2.1_GoodPractices.pdf

Nathanail, E.; Mitropoulos, L.; Adamos, G. 2016b. Research Educational and Training Program in Latvia and the Region. ALLIANCE Deliverable D2.2. Project No 692426 - Enhancing Excellence and Innovation Capacity in Sustainable Transport Interchanges. 53 p. Available from Internet: http://allianceproject.eu/wp-content/uploads/2017/02/ALLIANCE_D2.2. Research_Educational_Training_Program_Latvia.pdf

Hollands, R. G. 2008. Will the real smart city please stand up?, City: Analysis of Urban Trends, Culture, Theory, Policy, Action 12(3): 303-320. https://doi.org/10.1080/13604810802479126

LIAA. 2017. Investment and Development Agency of Latvia (LIAA). Available from Internet: http://www.liaa.gov.lv

Lowendahl, J.-M.; Thayer, T.-L. B.; Morgan, G. 2016. Top 10 Business Trends Impacting Higher Education in 2017. Available from Internet: https://www.gartner.com/doc/3556821/ top--business-trends-impacting

Lukovics, M.; Zuti, B. 2013. Successful universities towards the improvement of regional competitiveness: 'fourth generation' universities, in 53rd ERSA Congress: Regional Integration: Europe, the Mediterranean and the World Economy, 27-31 August 2013, Palermo, Italy, 1-17. https://doi.org/10.2139/ssrn.3022717

Mateo-Babiano, I. 2017. Understanding transport planning education in an Australian context, Transportation Research Procedia 25: 4311-4321.

https://doi.org/10.1016/j.trpro.2017.05.270

Mitropoulos, L.; Adamos, G.; Nathanail, E.; Yatskiv (Jackiva), I.; Kabashkin, I. 2017. Building on European scientific excellence to develop an educational program on intermodal connections for Latvia and the region, Transport 32(1): 79-93. https://doi.org/10.3846/16484142.2017.1280851
OECD. 2017. OECD Economic Surveys: Latvia 2017. Organisation for Economic Cooperation and Development (OECD), Paris, France. 140 p.

https://doi.org/10.1787/eco_surveys-lva-2017-en

TRB. 2016. Transformational Technologies in Transportation: State of the Activities. Transportation Research Circular E-C208. Transportation Research Board (TRB), Washington, DC, US. 86 p. Available from Internet: http://www.trb.org/ Main/Blurbs/174370.aspx 